\title{
記念講演
}

\section{最近 10 年間におけるわが国の医真菌学, 真菌症の動向と将来の展望}

\author{
1. 真菌の基礎的諸問題
}

\author{
山口英世
}

帝京大学医真菌研究センター

はじめに

過去 10 年間における医真菌学の研究の進展は, 基 礎, 臨床の諸分野を通じて実にめざましいものがある. その背景として, 第 1 には, 一般徽生物学, 免疫学, 分子生物学などの領域で新たに開発された方法論およ びそれによって得られた成果が真菌学の領域へ導入さ れたことがあげられる，第 2 に，真菌症ことに日和見 病原真菌に起因する深在性真菌症が近年增加の一途を 辿っている情況が, 真菌症の診断や治療といった臨床 面の問題に留らず, 病原真菌自体ならびにそれと宿主 生体とのかかわり合いといら基本的問題についても研 究者の関心をさらに強く呼び起こす効果を産んだ事実 を見逃せない。

今日の医真菌学が解明を迫られている最も中心的な 課題は, 真菌症の病因メカニズムにあることは論をま たない，当然のことながら，それに対するアプローチ は, 世界中の医真菌学者の手により寄生体たる病原真 菌の側とわれわれ哺乳動物宿主側の双方からなされて いる.こうした世界的な研究の流れのなかにあって, 近年わが国では数々の研究テーマに関して国際的水準 と超えたすぐれた業績が輩出するようになった。これ は, 日本医真菌学会を母体としてわが国の医真菌学研 究者が活ぱつな研究活動を行ってきた結果にほかなら ない.

今回日本医真菌学会創立 30 周年を記念し, わが国に 扣ける斯界の研究動向をらかがうことを目的として, 過去 10 年間本学会総会で発表された演題（特別講演, シンポジゥム，ワークショップなどを含む）のなかで 基礎領域に関するものを整理し，概観することを試み だ. 紙数の制限ならびに著者の能力の限界から，すべ

別刷請求先 : 山口 英世

₹ 192-03 東京都八王子市大塚 359 帝京大学医真菌研究センター
ての演題をカバーできなかった点抢よび内容の詳細に 立ち入れなかった点をご容赦頂きたい.

\section{病原真菌の生活史および分類・命名}

高等生物とは異なり, 真菌の生活史は必ずしも規則 的ではない，典型的な真菌の生活史は，有性世代（完 全世代）と無性世代（不完全世代）からなるが, 病原 真菌には不完全世代しか知られていないもの, 寸なわ ち不完全菌が少くない. 真菌, ことに糸状菌の分類は, ふつう有性世代にみられる生殖器官や形質が基準にな るので, 不完全菌の分類学的位置づけは, しばしば困 難になる.これに加えて, 完全世代と不完全世代に別々 の菌名が与えられていることに由来する命名上の問題 も少なからず起っている。このような場合, 国際命名 規約によれば, テレオモルフの学名がアナモルフの学 名に優先することが決められているのに, 病原真菌は ふつらアナモルフとして分離されるため, 後者の菌名 が一般に使用されているといら矛盾がこの分類, 命名 にかかわる問題を一層複雑にしている。このような理 由が背景となって, 幾つもの主要な病原真菌, とくに 皮膚系状菌, Sporothrix schenckii, Cryptococcus neoformans, Malassezia furfur, 黒色真菌拉よびカンジダに ついて検討がなされてきた。

これまで全体の約半数の皮膚系状菌, ことにTrichophyton および Microsporum 菌種について有性世 代がそれぞれ Arthroderma 拈よび Nannizzia 菌種で あることが知られている(長谷川, 1976). Trichophyton の臨床分離株に一方の交配型しかみられないことは従 来報告されているところである．近年 M. canis（完全 世代, N. otae) と M. gypseum (完全世代, N. gypsea) について臨床分離株の交配型が調べられ, 前者ではヒ

* 脚注: 感染免疫扣よび免疫・血清学についてはそれ ぞれ新井正博士，深沢義村博士によって述べられて いる(本誌掲載論文参照)ので, 本稿では省略する. 
卜由来株, イヌ由来株とも圧倒的に（一）交配型が多 いこと(広永ら, 1978 ; 高島ら, 1981；久保ら，1982)， 一方, 後者では同一患者から両交配型がかなり高い頻 度で分離されること(広永・渡辺, 1977 ; 広永ら，1980） が示されている。ささらに，広永（1981）は，A，vanbreuseghemii 関連菌種の系統発生的類縁関係を遺 伝学的に追究した。そのほか, 従来完全世代が不明で あった Epidermophyton floccosum に交配型が存在す ることが小澄ら（1982）および林・利谷（1984）によっ て証明され，松本 (1983) は, M. distortum が N. otae と交配可能であることから，これを $M$. canis の变種と 扱らべきであると提唱した。

S. schenckii の有性世代については, Mariatら （1968，1971，1973)が本菌に子囊殼を認めたことから ホモタリックの子囊菌 Ceretocystis stenoceras を想定 して以来，各国で活ぱつな研究が行われた。わが国で も幾つかの研究グループによっ Ceratocystis 属菌種 とS. schenckii の類縁関係が形態学的に (宮治, 1976) また血清学的に) 久石崎・仲村, 1976, 1978 ; 仲村・石 崎, 1977 ; 西川, 1976）検討され, さらに血清学的類 縁性は Streptococcus（石崎・仲村，1978）, Graphium, Europhium（仲村 - 石崎, 1977 ; 石崎 ら, 1979), Microascus, Petriellidium, Petriella (西村ら, 1978) といったさまざまな細菌や真菌菌種についても調べら れた.Ceratocystis との関係を明確にできない理由とし て西川（1982）はS. schenckii の菌種内（菌株間）不 均一性を指摘している。

Cr. neoformans の完全世代として Kwong-Chung （1975）が担子菌の新菌種 Filobasidiella neoformans を創設し，さらにその後 2 つの変種と対応する 4 つの 血清型の存在を見出して以来*，わが国でも $C r$. neoformans 臨床分離株について完全世代の検証（長 谷川ら，1977），交配型の遺伝解析（広永ら，1977）が 行われた。本菌の血清型执よび抗原多糖の免疫化学に 関する研究については本誌深沢博士の論文を参照され たい。

癜風の原因菌として知られる不完全酵母 Malassezia furfur (寄生形) と Pityrosporum orbriculare や P. ovale（培養形）との異同について以前から論争が あったが，近年いずれも同一菌種と見なされるように なった。宗ら（1978，1979）はこの点を指摘するとと

*脚注：これについては彼女自身が本学会総会で講演 した（1982）.
もに本菌に対する薬剤の抗菌試験法を考案した。

黒色真菌は，多彩な性状をもつ広範囲の真菌からな る便宜的な真菌群であり，その分類に関しては問題点 が多く残されている(加世田，1977；福代，1982)。わ が国に打いては伝統的に黒色真菌の研究が盛んである が，近年とくに注目を集めたのは，千葉大，西村ら (1979，1981，1982）による Exophiala dermatitidis の 分類に関して分生子形成様式に基づいて行った新提案 である。本菌はかつて Emmons (1963)により Phialophora 属 (P. dermatitidis)に分類され，その後 McGinnis（1977）は分生子にカラレッ上がなくフィアアライド を生じることを根拠にWangiella 属 (W. dermatitidis)に所属させたのであるが，西村らは走査 型電子顕微鏡観察により環紋形成を証明し，本菌がア ネロ型分生子をつくるといら理由から, Exophiala 属 （E. dermetitidis）に移すべきことを提唱した。また， 松本ら（1984）は本菌の有性世代が Sarcinomyces phaeomuriformis であると主張している.

西村・宮治（1983）は，黒癬原因菌について新たな 分類上の位置づけを行った。この黒色真菌はHorta （1921）が初めて分離に成功し, Cladosporium werneckii の菌名で記載し, その後 Artis, McGinnis, Cole など（1970）により本菌がアネロ型分生子をつく るとして, Exophiala 属に所属させることが提唱され ていた。西村・宮治は出芽痕の走査電顕像を解析し， 本菌がアネロ型といらょりむしろンンポジオ型に近い ユニークな分生子形成様式を歹っとして, 新属 Hor . taea を創設し, H. werneckii の菌名を与兄たのであ る.

不完全酵母の最大の属であるCandida の分類につ いては議論が多い。篠田（1982）はその問題点を指摘 するとともに，主として血清学的手法を用いて C. al bicans と抗原的に近似する菌種の分類学的関係を追 究した.

\section{真菌の無性胞子形成}

前項でも述べられているょらに，無性胞子ことに分 生子の形成の有無と形成される胞子の種類は, 真菌の 分類・同定上重要な基準になりらる。こうした理由か らか，無性胞子形成の観察を容易にするための培地条 件, 胞子形成過程の形態学, 胞子形成メカニズムなど の検討が次のようなさまざまな菌について行われてい る.（i ）C. albicans の厚膜胞子または分芽型分生子 （金子ら，1976；秋貞ら，1976；横山・竹尾，1981）, (ii) T. mentagrophytes の大分生子（新見・徳永, 
1978 ; 新見ら, 1979 ; 金子・長谷川, 1979, 1980), (iii) Rhinocladiella aquasperma（岩津 ら，1985)，(iv） Trichosporium heteromorphum, Microsporium mansonii (岩津ら, 1982).

\section{真菌の微細構造および細胞組織学}

分生子の形成様式や形成過程の解析に電子顕微鏡学 的手法がしばしば用いられることは既に述べた通りで ある。この方法論による真菌細胞全体，細胞壁または 細胞膜の微細構造に関する演題が多数見受けられる。 細胞壁については化学組成分析がしばしば併行してな されている。真菌細胞または構造体の超微形態学的研 究が比較的多いのは, わが国における医真菌学研究の 大きな特徵ともいえるが，これは電子顕微鏡の普及度 が高いことにも因るのであろう，走査型電子䫓徽鏡法 (SEM), 透過型電子顕微鏡法 (TEM), 凍結割断法 (FF)など目的に応じてさまざまな手法が用いられる。 この点で近年とくに注目されるのは, 急速凍結置換法 の真菌学領域への導入であり, 酵母細胞（大隅ら, 1984 ; 草道ら，1985）および糸状菌(神戸・田中，1984） を対象としてこの新しい手技による研究が行われつつ ある。

SEM を用いた細胞表層 (外形) の微細構造の解析 は, Aspergillus terreus (猿田ら, 1985)やC. albicans （徳永・徳永，1978）について行われている。 TEM な ぞによる細胞内部微細構造の解析は, C. albicans の菌 糸(村上ら, 1978, 1979 ; 原田, 1979), germ tube(田 中, 1983)扰よび厚膜胞子(竹尾ら，1979), Cr. neoformans (比留間ら, 1979), Alternaria alternata (増田, 1979)を対象としてなされている。一方，FFによる研 究としては, 主として野沢博士 (岐阜大) のグループ によって S, schenckii の細胞膜（前田・北島, 1978； 前田, 1979 ；前田ら，1980，1981)および E. floccosum の細胞膜（北島ら，1977）と細胞壁（北島，1978；野 沢，1981）に関するものが発表されている.

\section{真菌の生理学および生化学}

このカテゴリーに属する研究（表 1) は, 欧米諸国 にくらべて少ない傾向がうかがわれる。それでもC. albicans，皮䖉糸状菌をはじめ幾つかの病原性真菌に ついてさまざまな角度から研究がなされて抢り，用い られている方法論も電子顕微鏡法を含めて多彩であ る. 研究内容が多岐にわたるため詳細は省略するが, ユニークな研究に乏しい感があることは否めず, 今後 わが国においてはとくにこの領域の研究を発展させる 必要があろう。
表 1 過去 10 年間に日本医真菌学会総会に打いて発 表された病原真菌の生理, 生化学的研究に関する 演題の内容項目および試験菌別内訳

\begin{tabular}{|c|c|c|}
\hline 内容項目 & 試 験 菌 & 発 \\
\hline 発育と栄養 & $\begin{array}{l}\text { 皮詹糸状菌 } \\
\text { S.schenckii } \\
\text { Pityrosporum }\end{array}$ & $\begin{array}{l}\text { 北村ら (1984) } \\
\text { 金子ら (1981) } \\
\text { 加藤・香川(1983) }\end{array}$ \\
\hline 温度感受性（抵抗 & $\begin{array}{l}\text { S.schenckii } \\
\text { 皮庵糸状菌汪か } \\
\text { Curvularia trifolii }\end{array}$ & $\begin{array}{l}\text { 比留間 }(1978,1985,) \\
\text { 仲 }(1981) \\
\text { 大郷ら }(1984) \\
\text { 江口ら (1985) }\end{array}$ \\
\hline $\begin{array}{l}\text { プロトプラスト： } \\
\text { 調製法と再生 }\end{array}$ & $\begin{array}{l}\text { C.albicans } \\
\text { T.mentagrophytes }\end{array}$ & $\begin{array}{l}\text { 神戸ら (1980) } \\
\text { 河ら (1985) }\end{array}$ \\
\hline 発芽管形成 & C.albicans & $\begin{array}{l}\text { 長ら(1984), } \\
\text { 草道ら(1982, } 1983)\end{array}$ \\
\hline cAMP 代謝 & C.albicans & 新見, 徳永 (1982) \\
\hline 産生色素 & 皮膚系状菌 & $\begin{array}{l}\text { 秋田ら(1978), } \\
\text { 牧野(1980) }\end{array}$ \\
\hline $\begin{array}{l}\text { 菌体脂質またはリ } \\
\text { ソ脂質組成 }\end{array}$ & $\begin{array}{l}\text { 皮膚糸状菌 } \\
\text { C.albicans }\end{array}$ & $\begin{array}{l}\text { 山田ら (1976, 1979), } \\
\text { 鹿野ら (1985) } \\
\text { 松原 (1985) }\end{array}$ \\
\hline 脂質代謝酵素 & C.albicans & 坂野ら (1984) \\
\hline キチン合成酵素 & C.albicans & $\begin{array}{l}\text { 森田・野沢 (1985), } \\
\text { 柳沼ら (1983) }\end{array}$ \\
\hline 細胞壁構成成分 & $\begin{array}{l}\text { E. floccosum } \\
\text { A.niger } \\
\text { G.candidum }\end{array}$ & $\begin{array}{l}\text { 野沢(1981) } \\
\text { 関谷ら(1978) } \\
\text { 関谷ら(1978) }\end{array}$ \\
\hline
\end{tabular}

\section{真菌の生殖と遺伝}

このカテゴリーの研究テーマは比較的少数に限られ ているが，特定の研究グループによって系統的な研究 が行われている。その好例は，渡辺博士（滋賀医大） のグループによる A. vanbreuseghemii, $N$. otae およ び F. neoformans に打ける有性生殖過程の超徵形態 学的研究（田中・渡辺，1980；藤垣ら，1981；田中ら, $1981 ， 1982 ， 1984$ ，望月ら，1983，1984，1985）や田 中博士（名大）のグループによる不完全酵母 C. albicans 生殖過程の細胞学的解析, ことに核分裂および 細胞分裂に伴う核相変化に関する研究（田中, 1983 ; 田中・鈴木， 1981 ; 鈴木・田中，1983；神戸ら，1983） にみられる。後者の研究においては, Van der Walt （1967）による “sexually active-strain”の見直しがな され，さらにC. albicans 栄養要求株間の mitotic recombination を利用することによって多倍数性と異 型接合性について詳細な解析を行って, 本菌遺伝解析 への道を拓いた点は高く評価されよう。

そのほかの研究としては, 皮膚系状菌有性世代誘導 条件の検討（本間ら，1982；西本・本間，1985）やC. 
albicans からの栄養要求株その他の変異株*の誘導・分 離(山口, 1981 ; 神山, 1982)がある.ことに従来“petitnegative”と見なされてきた C. albicans から呼吸欠損 変異株が分離された成績（山口，1981）は注目される.

このように, 病原真菌に関する遺伝学的研究はよう やく緒についたばかりであるが，近い将来に病原因子 や薬剤耐性を支配する遺伝子の存在が明確になれば, この方面の遺伝解析は大いに進展するものと期待され る.また,これを促進するために適当な宿主一ベクター 系を用いた遺伝子工学的手法やプロトプラスト融合な どの細胞工学的手法の導入が必要となろう.

\section{二 形 性}

二形性とくにその生化学面に関していえば，世界的 な動向としてはMucor 菌種およびHistoplasma capsulatum を対象とした研究が最も進んでいる.一方,わ が国ではこれらの真菌になじみがらすいせいか, 二形 性の研究は C. albicans に集中する傾向がみられる.こ の菌を中心に幾つかの二形性真菌について形態学, 生 理, 生化学および遺伝学の面からさまざまなアプロー チがなされている。

(i) 形態学的アプローチ In vitroおよび（または） in vivo 形態変換の過程が, S. schenckii, H. capsulatum, Coccidioides immitis（西村・宮治， 1977 ; 宮治 ら，1980)および Paecilomyces lilacinus（松田ら，1984） について観察されている。この研究に際して, 宮治博 土(千葉大)のグループは，「マウス腹腔内寒天埋没法」 というユニークな手法を用いた。 二形性形態変換過程 の超徵形態学的研究としては, 前田ら（1982，1983） によるS. schenckii 細胞膜構造の変化および神戸ら (1982) による C. albicans の germ tube に関するもの がある。

(ii) 生理, 生化学的アプローチ 最も多数でしかも 多彩な内容の研究が行われている，第 1 は, 形態変換 に及ぼす培養条件の検討であり, これは C. albicans （新見・徳永， $1978 ；$ 長ら，1985）および T. mentagrophytes, F. pedrosoi, E. dermatitidis (占部, 1980) に ついてなされている.

第 2 は, 発育形態を最終的に支配する細胞壁の化学 組成とくに細胞壁の骨格構造をなす多糖とその構築に 関する研究である. 金綱 (1978, 1983) は, Paracoccidioides brasiliensis, Blastomyces dermatitidis および H. capsulatum の酵母 (Y) 形と菌系 (M) 形との間で

* 脚注：二形性に関連する変異株については次項参 照.
細胞壁多糖組成を比較するとともに, P. brasiliensis に おける $\mathrm{Y}$ 形 $\rightarrow \mathrm{M}$ 形変換のモデルを提唱した．．．ａlbicansに拈いては，Y 形の壁にくらべて $\mathrm{M}$ 形の壁の ほらがキチン含量に富むといわれている。矢野ら (1980)は, M 形細胞膜由来のキチン合成酵素活性が Y 形由来のものよりも高いことを示した.C. albicans 細 胞壁については, マトリックスとして重要なホスホマ ンナンタンパク複合体の両形間での生化学的相違が調 ベられている(柴田ら，1984）。同様に, M. rouxiiに おける細胞壁マンナンの構造が両形間で比較検討され た（山田ら，1980）。

細胞壁多糖を合成する酵素は，いずれも細胞膜に存 在しているので, 細胞膜の化学組成とくに脂質組成は, これらの合成酵素活性の調節に関与するものと考えら れる.この想定に立って, 特定の二形性真菌の $\mathrm{Y}$ 形と $\mathrm{M}$ 形それぞれの全菌体または単離した細胞膜標品に ついて脂質分析が行われ，形態変換に伴ってどのよう に変動するかが調べられている．C. albicans に関して は，脂質全般の組成（山田ら，1980；森田ら，1984）, 菌体脂肪酸組成（山口・岩田，1979），リン脂質分子種 扣よびアシル鎖（矢野ら，1981；山田ら，1982）が, また S. schenckii に関しても菌体脂質組成（鹿野ら， 1984）が，いずれも分析されている.

第 4 は, H. capsulatum や Mucor spp.でかなり詳細 に調べられているサイクリックヌクレオチドと二形性 との関係についての研究である、新見ら (1979) は $C$. albicansに打ける二形性と細胞内cATP执よび cGTPレベルとの相関性を調べた.

第 5 は，細胞内タンパクの分析である。二形性にか かわる遺伝子の産物として, 形態形成に伴って変化す る特異タンパクの検索が C. albicans（横山ら， 1985） やS. schenckii(仲ら, 1983)について試みられている.

（iii）遗伝学的アプローチ C. albicansにおいて, 二形性にかかわる変異株の分離ならびに性状の解析が なされている(竹尾ら，1979；荻原ら，1983；津村ら， 1984).ささらに, 鈴木ら (1981, 1982)により, ploidy と二形性との関係が調べられている.

真菌の病原性（または毒力）の評価法

真菌（菌株）の病原性（毒力）を実験的に評価する ことは, 患者検体からの分離菌の病因的意義の確立ま たは真菌症動物モデル作成に好適な菌株の選択に必要 であるばかりでなく, 真菌症の疫学, バイオハザード の予防対策, 有用微生物の安全性確保などの観点から も重要である.SCP 開発研究が盛んだった 1970 年代 
中頃には，そらした情況を反映してメタノール資化酵 母その他の有用酵母の病原性の評価に関する報告が相 次いでなされた（岩田ら，1976；奥平ら，1976；上塚 ら，1976；岩田・内田，1978）。一部ミニブタを使用し た例を除くと，大部分の場合には，正常マウスまたは ステロイドホルモン前処置マウスに試験酵母をi.v.接 種した後, $\mathrm{LD}_{50}$ 值 (または死亡率) や病理組織学的所 見に基づいて病原性を評価するといら方法が用いられ ている。基本的に同じ方法は，下記のさまざまな病原 性真菌の保存株または臨床分離株の病原性を調べるの にも用いられてきた。（i ）C. albicans その他のCandida 菌種（加賀谷ら，1978，1980; 内田ら，1983；吉 山ら, 1983 ; 村瀬ら, 1985), (ii) Cr.neoformans (山 田ら, 1980 ; 加賀谷ら, 1984), (iii) Exophiala 属黒色 真菌（西村・宮治，1982）。一方，Fusarium について は，ウサギにおけるi.v,感染または経気道感染の実験 系が使用されている(井門ら，1984)。これらの全身的 感染とは別に, 角膜真菌症の起病力を調べる目的で, 石橋博士（筑波大）のグループは, 臨床材料から分離 される Fusarium 菌種一F. solani, F. oxysporum, F. moniliforme-, C. albicans, Cylindrocarpon tonkinense などのウサギ角膜内接種を行っている（石崎 ら, 1979, 1980 ; 石橋・香川, 1981 ; 石橋, 1983).

\section{病原性への関与が想定される真菌毒素}

\section{または二次代謝産物}

これは医真菌学領域に括ける最も大きな研究分野で あるとい充よう。わが国でも従来から多数の研究報告 がなされ，下記のように種々の真菌から毒性をもつさ まざまなタイプの物質が分離されている.いずれも in vitro 系においては, 明らかな生物活性を示すものの, その産生が同一菌種内でも特定の菌株でしか証明され なかったり, in vivo で活性を発揮している証拠が得ら れなかったりして，病因的意義が真に確立された例は まだ活とんどなく、今後さらに追究されねばならない。

(i) 高分子毒素 岩田博士(東大, 明薬大)のグルー プは, C. albicans 由来のタンパク毒素 canditoxin に 引き続いて，マンナンータンパクなどの構造をもつ新 たな糖タンパク毒素を分離し，種々の生物学的性状を 調べるとともに，実験動物に対する生化学的ならびに 薬理学的影響を検討した（平谷・岩田，1976，1977， 1978 ; 山本・岩田, 1976, 1977, 1981; 岩田・平谷, 1979）。さらに同研究グループは, 従来ほとんど報告を みなかった二形性病原真菌の病原因子を検討し, 細胞 毒性や致死毒性を示さないものの, マイトジェン刺激
マウス脾リンパ球幼若化に対して阻害活性をもつ易熱 性高分子物質を H. capsulatum より分離した（神宮ら， 1983)。一方, 坂口博士 (東北薬大) のグループは, 以 前より研究を続けてきた A. fumigatus 由来の溶血性 タンパク毒素 Asp-hemolysin の生物学的活性拈よび 動物に対する臨床生化学的影響を検討した（横田ら, 1981 ；蝦名ら，1983）.

(ii）タンパク分解酸素その他の分解酵素 Z゚ロテ ア一ゼは，C. albicans の病原因子として目下世界的に 最大の関心を集めて抢り,わが国でも田中博士(名大) のグループによる追試が行われている(清水ら, 1984 ; 近藤ら，1984）。㐬た A. fumigatus が産生するプロテ アーゼについても本菌病原性との関連が検討されてき た(宮治ら，1976；横田ら，1980)。皮膚系状菌が産生 するプロテアーゼとくにケラチナーゼは，これが表皮 角質層に打ける本菌の発育に必須であるところから，

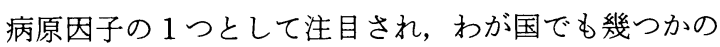
グループによって検討が進められている。なかんずく 研究が集中しているのは, 皮膚出状菌ヶラチナ一ゼの 基質特異性そのほかの酵素化学的特性(桶口ら, 1977 ; 広永ら, 1979 ; 滝内ら，1979；広谷ら，1984）および 病巣内局在性（清ら，1981；古賀ら，1984）である. ケラチナーゼに関しては, C. albicans 表在性感染にお いても同様の病因的役割を持つと考学られ，検討がな されている (門田, 1976). 小川博士 (順大) のグルー プは, Rewold (1968) や Rüchel (1981) が報告してい るものと類似の酵素を単離・精製し，その性状を詳細 に調べている(広谷ら，1984；松田ら，1985)。上西・ 荻原（1985）は，歯の象牙質をつくっているコラゲン を分解する活性（コラゲナーゼ活性）をむつプロテアー ゼをC. albicans が産生することを見出した。 これは本 菌の歯科領域に拉ける病因機序を解明する手掛りを与 えるものとして注目される.

C. albicans に扔いては, プロテアーゼとならんでホ スホリパーゼもまた何らかの病因的意義をもつ可能性 が考えられている。この酵素について, 前述の二形性 に関係する膜の脂質代謝の観点から（坂野ら，1983）, さらには川崎病との関連から（村田，1983）検討が行 われている。

（iii）アミン類 皮膚系状菌やC. albicans による皮 膚真菌症の臨床症状発現に関与する因子として, これ らの病原菌が産生するアミン類を想定し，代謝面その ほかさまざまな角度からこの化合物を詳細に検討した 田中博士（大阪医大）のグループの息の長い研究は, 
そのユニークさの点では特筆されるべきものであろう (田中ら, 1976, 1977, 1979, 1980, 1981, 1982, 1983, 1984, 1985).

（iv）皮膚系状菌細胞壁色素 以前より伊藤・野沢両 博士（岐阜大）のグループは, さまざまな皮膚糸状菌 菌体とくに細胞壁から色素を単離し，それらの化学的 ならびに生物学的性状を明らかにするといら一連の研 究を行ってきた. 比較的最近においても, M. cookei か ら分離された xanthomegnin (河合ら, 1976) やE. floccosum が産生する floccosin（河合・野沢，1981）に ついて細胞毒性または細胞膜機能に及ぼす影響などが 検討されている.

（v）マイコトキシンこれに関する本学会での発 表は比較的少ないが，奥平博士（北里大）のグループ は，実験動物における aflatoxin $\mathrm{B}_{1}$ および ochratoxin A の急性毒性と慢性毒性を病理組織学面から追求し た（奥平・久米，1979，1980；奥平ら，1981）。新井ら (1979)は, Paecilomyces lilacinus の生産する低分子毒 素 leucinostatin が本菌に起因する角膜炎の発症にか かわることを実験的に証明した。この研究は, 真菌由 来の低分子毒素がその菌による感染症を成立させるた めの病原因子として働く可能性を示唆して興味深いも のがある。

\section{宿主一寄生体関係}

病原体（真菌）が宿主生体に接種された場合に，感 染が成立するか，とれとも不成立に終るか，また感染 が成立したとしても, それが重症型へ進展するか否か, これらはすべて寄生体側因子すなわち病原因子と宿主 側因子すなわち感染防御機構との相互的関係によって 決まる。したがって，感染機序の解明には寄生体側お よび宿主生体側双方からのアプローチが当然必要であ り, わが国の医真菌学領域の研究者によっても多くの 研究がなされてきた，特異的感染防御機構すなわち感 染免疫については本誌新井博士の論文に詳しいので, ここでは真菌感染に対する非特異的防御機構について のみ取り上げる。

寄生体側因子としての真菌毒素扣よび毒性二次代謝 産物に関しては前項で述べた。自然感染または実験感 染 (動物) に拈ける真菌の寄生形態および（または） それに対する組織反応の超微形態学的観察や病理組織 学的観察は, 次にあげるように, 生体内の様々な臓器・ 組織内の種々の病原真菌についてなされている。（i ） 毛髮内の Allescheria boydii（高島・宇田川, 1978), Microsporum canis (原田, 1983 ; 神戸, 1985 ；鈴木ら,
1985）およびM. gypseum（神戸・田中，1981），(ii） 腹腔内の Trichophyton rubrum, T. mentagrophytes および M. canis（西山ら，1983），(iii）脳または皮下 組織内の黒色真菌一とくにFonsecaea pedrosoi, Exophiala dermatitidis, Cladosporium trichoides, $C$. minourae (原田ら, 1981 ; 西村, 1983 ; 岩津, 1984), (iv)肝内での Coccidioides immitis (宮治・西村, 1983).

宿主側の組織反応の病理組織学的解析に焦点を合わ せた研究として, 次のものが発表されている.（i ）脳, 肝内での Cryptococcus neoformans（渡辺ら，1983）,

(ii）真皮内でのC. albicans（奥田ら，1983），(iii） 種々の臓器内での C. albicans, Aspergillus fumigatus, Rhizopus oryzae (発地ら, 1979), (iv) 腹腔内での $T$. rubrum（西山・宮治，1982），(v）肺または全身皮膚 に打ける Fusarium(崔ら，1984，1985；井門ら 1985)。

感染成立に関与するより明確な寄生体側因子とし て, 田中博士 (名大) のグループは C. albicans その他 のCandidaのヒト口腔粘膜や HeLa 細胞に対する付 着能を(近藤ら，1981；清水ら，1982，1983）, また深 沢博士（山梨医大）のグループは C. albicans および Cr.neoformansについて食細胞および（または）食細 胞内殺菌系に対する抵抗性を(鈴木ら，1981；深沢ら， 1982 ；加賀谷ら，1983）それぞれ追究している.

一方, 宿主側の感染防御機構に関しては, 次のよう な食細胞を対象とした研究がとくに目立っている. （i ）C. albicans に対する食作用（徳永ら，1978；徳 永. 徳永, 1979), (ii) S. schenckii に対する食作用(蜂 須賀ら, 1979：比留間-香川, 1983), (iii）白癬病巣 に拈ける遊走機序(田上ら，1979）。また宮治ら(1983) は, 脾摘マウスを用いて Cr. neoformans や S. schenckii の感染に拈ける脾臓の役割を検討している.

ある種の真菌症に拈いては, 鉄代謝が大きく影響し ているようである.この問題に関しては, 鉄飽和 transferrin の抗真菌作用が調べられている(白石ら, 1976 ; 白石. 新井, 1977). また transferrin との関係は不明 であるが，鉄投与による実験カンジダ症への増悪効果 (阿部ら，1983）や糖尿病マウスに拈ける実験的接合菌 症と鉄結合能 (UIBC) との関係（阿部ら, 1983）が検 討されている。

皮膚真菌症の主たる病巣となる表皮には幾つもの特 殊な感染防御機構が働いていることは極めて興味深 い.この問題に関しては次のような因子または機構の 存在と役割が検討されている.（i ）皮膚系状菌のケラ 
チナーゼに対する阻害因子一 $\alpha_{2}$ マクログロブリン（小 川，1982；脇元ら，1982），(ii）抗カンジダ活性をも つ cationic protein(高橋ら，1981),（iii）C. albicans に対する transepithelial elimination mechanism（松 尾ら，1982）.

\section{実験的真菌感染および真菌症動物モデル}

真菌症成立機序の解明には無論のこと, さらに真菌 症の診断や治療の研究を行う上でも, 実験動物におい て作成された好適な感染モデルの使用は不可欠であ る。このよらな理由からさまざまな真菌症モデルがそ れぞれに適した実験動物で作られている。

（i）深在性または全身性感染 種々の遺伝的背景を もったマウス系統や前処置を施されたマウスに病原真 菌を静脈内接種することによって全身性感染がつくら れている。わが国ではヌード (nu/nu) マウスを好んで 使用する傾向があり, C. albicans 感染(新井ら, 1977), A. fumigatus 感染(白石ら，1977，1978)，Cr.neoformans 感染（西村・宮治，1978），H. capsulatum 感染 （宮治ら，1980）などがつくられている。さらにC. albicans 感染は担ガンマウス（横山ら, 1977 ; 梅内ら, 1979）や白血病マウス（阿部ら，1982）でもつくられ ている. 白血病マウスは A. fumigatus 感染の実験にも 使用されている(阿部ら，1983）.

深在性カンジダ症は, 消化管に常在する C. albicans により内因的に成立するのがふつうとされている。こ の感染機序を究明するための動物モデルとして，ステ ロイドホルモン（打よび抗生物質）前処置を受けたマ ウスに対してC. albicansを経口接種することにより 全身性カンジダ感染モデルがつくられ, 種々の解析が 行われている（梅田・紺野，1977；内田ら，1985）。

(ii）経鼾接種または経気管推種による肺感染こ れらの接種法により, 感作ウサギに打けるA. fumigatus 肺感染（井門ら, 1981; 発地, 1982) や C. albicans 肺感染 (中地・発地, 1982) 拈よび正常マウス に打ける Cr. neoformans 感染（伊藤ら，1985；内田 ら，1985）がつくられている.

（iii）カンジダ性腎孟腎モデル 外科的前処置を施 したマウスの膀胱内に C. albicans を接種し, 亜急性上 行性腎孟腎炎が作成された(押ら，1981，1982，1985)。

(iv) 腟カンジダ症モデル エストロダン処置マウ スの腔内にC. albicansを接種することにより本症モ デルがつくられた（山本・岩田，1982；掘見，1984）。

（v）角膜真菌症モデル 石橋博士（筑波大）のグ ループは，独自の角膜内接種法を用い，ウサギにおい
てF. solani, F. oxysporum, C. albicans などによる角 膜真菌症のモデルを作成し，これを治療実験にも使用 した（石橋ら，1979；石橋・香川，1981，1982；桐生 ら, 1982).

（vi）白㿍モデル モルモットの背部に皮膚系状菌 の分生子を接種してつくられる従来型の実験的白澭 （島津ら，1985）に加兄て, 藤田ら（1985）が開発した occulsion 法を用いての分節胞子接種によるモルモッ トの足白巕モデルは，対応するヒトの自然感染の病態 により一歩近づいたという意味で注目される。

（vii）動脈资モデル 真菌に由来する非感染性病態 モデルとして, 村田博士（東邦大）のグループは $C$. albicans 菌体成分の動物接種により川崎病様の動脈炎 を作成し,病理組織学的に詳細な比較検討を行った（村 田，1977；直江ら，1977，1982，1983，1984；村田・ 飯島，1978，1980；村田ら，1984）.川崎病原因究明が 緊急な課題となっているだけに，病因論的にもこのモ デルは興味深い。

\section{生物学的応答修飾物質 (BRM)}

下記に記すように，幾つもの真菌や細菌の菌体成分 について，実験的真菌感染症に捛ける宿主側免疫応答 の BRM としての活性が調べられている。これらの BRM は, 多くの場合, 真菌感染に打ける宿主生体の免 疫応答の意義または感染過程の修飾因子としての役割 を解析するために使用されるか，さもなければ真菌症 や癌の免疫療法への応用を目指して検討されている.

（i） S. cerevisiae マンナン（大倉ら，1981，1984；鈴 木, 1982 ; 大川ら, 1984, 1985), (ii) キチン/キトサ ン（大川ら，1982；鈴木ら，1983). (iii) C. albicans アルカリ不溶グルカン（岩田・山本，1979）。（iv）担 子菌グルカン(宮崎, 1982). (V) PS-K(上塚ら，1977， 1978，1979，1980，1981，1985；大野ら，1982).(vi) LPS (阿部ら，1985)。（vii） muramyl dipeptide 拈よ び関連化合物(岩田ら，1980；鍛代ら，1982；安江ら, 1983 ; 阿部ら，1985). (viii) 2-methyl streptimidane （梅内, 1978).

\section{真菌由来抗原活性物質の生物活性と化学}

下にあげた主として糖（多糖）とペプチドからなる 種々の真菌の菌体または培養汇液から得られる抗原物 質について，抗原活性（皮内反応）や化学構造が調心 られている。（i ) Absidia cylindrospora その他の接 合菌由来のフコマンナンーペプチド（林ら，1976, 1977). (ii ) F. pedrosoi その他の黒色真菌由来の多糖 ーペプチド(岩津ら, 1977, 1979, 1980 ; 本房ら, 1983). 
（iii）皮膚系状菌細胞壁多糖（川原崎，1978；生富ら， 1978 ; 荻原ら, 1979). (iv) S. schenckii 拉よび関連菌 由来の多糖一ペプチド（倉田, 1979 ; 高田, 1981 ; 真 下ら, 1983).

\section{病原真菌の分離と同定}

下記の内容の研究が発表されている. (i) 医学的に 重要な酵母の同定法一とくに基準化を目標としたもの （深沢ら, 1976 ; 篠田ら, 1977, 1979), (ii) API-20C,
カンジダチェックなどの酵母同定用キットの評価（岩 田ら，1977; 篠田ら，1980），（iii）皮膚系状菌分離・ 同定用キット“Dermatoslide Roche”の評価(阿部ら； 1983)。（iv）酵母同定用自動化装置（AMS など）の評 価 (奥住ら，1983），（v）組織内菌要素の細胞化学的 検出, 同定法一酵素抗体法（小林ら，1984）。（vi）血 液, 髄液, 䔬便, 結膜, 胵などの臨床材料についての 真菌検索(松島, 1976; 築地ら, 1981; 佐野ら, 1982 ;

表 2 過去10年間に日本医真菌学会総会において発表された抗真菌剤の in vitro および（または）in vivo 抗菌試験に関する演題内訳

\begin{tabular}{|c|c|c|c|c|}
\hline & \multirow[b]{2}{*}{ 抗真菌剤 } & \multirow[b]{2}{*}{ In vitro 抗菌試験 } & \multicolumn{2}{|c|}{ In vivo 抗菌試験 } \\
\hline & & & $\begin{array}{c}\text { モルモットにおける } \\
\text { T.mentagrophytes 局 } \\
\text { 所感染 }\end{array}$ & $\begin{array}{l}\text { マウスにおける } \\
\text { C.albicans i.v. } \\
\text { 感染 }\end{array}$ \\
\hline \multirow{3}{*}{ 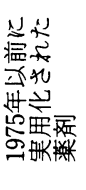 } & Amphotericin B & $\begin{array}{l}\text { 楠・Padhye(1980), 法月 } \\
\text { ら(1984) }\end{array}$ & & \\
\hline & Griseofulvin & $\begin{array}{l}\text { 楠・原田(1981), 楠(1982), 法 } \\
\text { 月ら (1984) }\end{array}$ & & \\
\hline & Tolnaftate & 楠ら (1985) & & \\
\hline \multirow{15}{*}{ 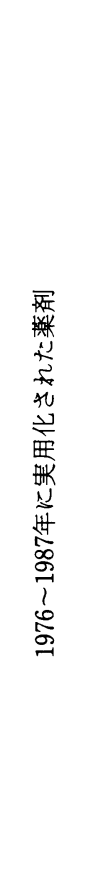 } & Clotrimazole $\left(1976^{a}\right)$ & $\begin{array}{l}\text { 楠 - 原田(1981), 楠(1982), 高 } \\
\text { 田ら(1983), 楠ら (1985) }\end{array}$ & & \\
\hline & Flucytosine(1979) & 久米ら(1981), 法月ら(1983) & & \\
\hline & Fxalamide (1980) & 楠・原田(1981)，楠(1982) & & \\
\hline & Miconazole $^{\text {b) }}(1981)$ & $\begin{array}{l}\text { 岩田ら (1976), 江川(1977), 楠・ } \\
\text { 原田(1981), 楠(1982), 法月ら } \\
(1983), \text { 楠ら (1985) }\end{array}$ & & \\
\hline & Ciclopiroxolamine & 楠ら(1985) & & \\
\hline & Econazole & $\begin{array}{l}\text { 山崎(1977), 楠・原田(1981), } \\
\text { 楠(1982), 楠ら (1985) }\end{array}$ & & \\
\hline & Isoconazole(1982) & 楠(1982), 楠ら(1985) & & \\
\hline & Tolciclate (1984) & 楠ら(1985) & & \\
\hline & Tioconazole (1984) & 楠ら(1985) & & \\
\hline & Oxiconazole(1986) & 楠(1982)，楠ら(1985） & & \\
\hline & Cloconazole(1986) & $\begin{array}{l}\text { 楠(1982), 俵 ら(1983), 楠ら } \\
\text { (1985) }\end{array}$ & 俵ら (1982) & \\
\hline & Sulconazole(1986) & $\begin{array}{l}\text { 楠(1982), 岩田ら (1982), 楠ら } \\
\text { (1985) }\end{array}$ & 岩田ら (1982) & \\
\hline & Miconazole $^{c}(1986)$ & & & \\
\hline & Bifonazole(1987) & 楠(1982)，岩田ら(1982) & 岩田ら (1982) & \\
\hline & Ketoconazole(1987) & $\begin{array}{l}\text { 楠・原田(1981), 楠(1982), 法 } \\
\text { 月ら (1984) }\end{array}$ & & $\begin{array}{l}\text { Shigematsu ら } \\
\text { (1980), 岩田ら } \\
\text { (1980), 皆川ら } \\
\text { (1981) }\end{array}$ \\
\hline \multirow{6}{*}{ 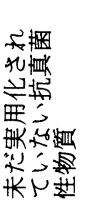 } & Aculeacin A & 岩田ら(1978), 鳥屋ら (1979) & & 岩田・内田(1979) \\
\hline & Copiamycin & 新井ら (1983) & & \\
\hline & Bay n 7133 & 山下ら (1983) & & 山下ら (1983) \\
\hline & Piritetrate & 岩田ら (1984) & 岩田ら (1984) & \\
\hline & MH-6 & 宇野ら (1985) & & \\
\hline & Methiodine & 今村ら (1985) & & \\
\hline
\end{tabular}
a ）上市された年次
b ）外用剤
c ) 注射剂 
船橋, 1984 ; 人見ら, 1976 ; 東出ら, 1978 ; 吉村 $\cdot$ 上 塚, 1978 ; 安藤 - 高島, 1979 ; 久保田 - 高田, 1983).

菌株保存技術

病原真菌の標準株や貴重な臨床分離株を良好な状態
で安定に保存しておくことは，医真菌学のあらゆる分 野の研究に不可欠の条件である。しかしながら，実際 には，保存技術に関する研究は少なく，しかも発表さ れる演題数は明らかに減少傾向にある。今後のこの面

表 3 過去 10 年間に日本医真菌学会総会に括いて発表された抗真菌剂の作用機作に関する演題内訳

\begin{tabular}{|c|c|c|c|c|c|}
\hline \multirow{2}{*}{ 抗真菌剤 } & \multicolumn{3}{|c|}{ 生理・生化学的研究 } & \multirow{2}{*}{$\begin{array}{l}\text { 電子顕徵鏡 } \\
\text { 学的研究 }\end{array}$} & \multirow{2}{*}{$\begin{array}{l}\text { 想定作用機作 } \\
\text { (作用標的分子) }\end{array}$} \\
\hline & 細 胞 系 & 無細胞系 & 人工膜モデル系 & & \\
\hline Amphotericin B & $\begin{array}{l}C . a .^{\text {a) }} \text { (関谷, 野沢, } \\
1981)\end{array}$ & & $\begin{array}{l}\text { 野沢ら (1978, } \\
1979) \text {, 野沢・梅本 } \\
(1979) \text {, 野沢・大本 } \\
(1980)\end{array}$ & $\begin{array}{l}\text { C.a. (関谷・野沢, } \\
1981)\end{array}$ & $\begin{array}{l}\text { 細胞膜障害(細胞膜エルゴ } \\
\text { ステロール) }\end{array}$ \\
\hline Flucytosine & $\begin{array}{l}\text { C.a.(山口・岩田, } \\
1977 \text {; 新开 } 5, \\
1978 \text {; 吉山ら, } \\
1982 \text { ) }\end{array}$ & & & & $\begin{array}{l}\text { DNA 合成阻害, 異常 RNA } \\
\text { 生成 }\end{array}$ \\
\hline Clotrimazole & C.a. (平谷 5 , & & 山ロ・岩田(1976) & & $\begin{array}{l}\text { エルゴステロール合成阻害 } \\
\text { (C-14脱メテル反応) }\end{array}$ \\
\hline Miconazole & 1985) & & " & & 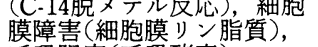 \\
\hline Econazole & $\begin{array}{l}\text { C.a. (山口 · 岩田, } \\
1978,1979 ; \text { 平 } \\
\text { 谷, } \\
1985 \text { ) }\end{array}$ & & "1 & $\begin{array}{l}\text { B.d.(岩田ら, } \\
\text { 1977)S.c.(岩田ら, } \\
\text { 1979) }\end{array}$ & 呼吸阻害(呼吸酵素) \\
\hline Isoconazole & $\begin{array}{l}\text { C.a. (末納ら, } \\
1981)\end{array}$ & & & & \\
\hline Bifonazole & $\begin{array}{l}\text { C.a.(山口・平谷, } \\
\text { 1983) }\end{array}$ & & & $\begin{array}{l}\text { T.m. } \\
1983)\end{array}$ (大隅 5, & \\
\hline Ketoconazole & $\begin{array}{l}\text { C. } a \text {. (宇野ら, } \\
1981 \text {; 新井・宇野, } \\
1985 ; \text { 上5, } \\
1983,1984 ; \text { 平 谷 } \\
\text { 5, } \\
1985)\end{array}$ & & 山ロら (1981) & & \\
\hline Bay n 7133 & $\begin{array}{l}\text { C.a. (平谷·山口, } \\
\text { 1983; 平谷ら, } \\
\text { 1985) }\end{array}$ & & & & $\begin{array}{l}\text { エルゴステロール合成阻害 } \\
\text { (C-14脱メチル反応) }\end{array}$ \\
\hline Tolnaftate & $\begin{array}{l}\text { C.a.(森田・野沢, } \\
\text { 1985) }\end{array}$ & $\begin{array}{l}\text { C.a.(森田・野沢, } \\
\text { 1985) }\end{array}$ & & & $\begin{array}{l}\text { エルゴステロール合成阻害 } \\
\text { (スクアレンェポキシダー } \\
\text { ゼ) }\end{array}$ \\
\hline Tolciclate & $\begin{array}{l}\text { S.s. (平谷・山口, } \\
1984 \text { ) }\end{array}$ & & & $\begin{array}{l}T . m \text {. (大隅ら, } \\
1983 \text { ) }\end{array}$ & " \\
\hline Naftifine & $\begin{array}{l}\text { S.s. (渡辺ら, } \\
1981 \text { ) }\end{array}$ & $\begin{array}{l}\text { S.c. (渡辺ら, } \\
1981 \text { ) }\end{array}$ & & & 細胞壁多糖合成阻害? \\
\hline Ciclopiroxolalmine & $\begin{array}{l}\text { C.a. (山口 • 岩田, } \\
1978,1979)\end{array}$ & & & & 細胞膜輸送 (ATPase?) \\
\hline Variotin & $\begin{array}{l}\text { S.s. (平谷ら, } \\
1981 \text { ) }\end{array}$ & $\begin{array}{l}\text { S.c. (平谷ら, } \\
1981 \text { ) }\end{array}$ & & & 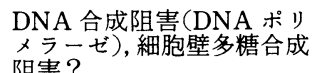 \\
\hline Pyrrolnilrin & $\begin{array}{l}\text { C.a.(山口・岩田, } \\
\text { 1979) }\end{array}$ & & & & $\begin{array}{l}\text { 阻害? } \\
\text { 細胞膜障害 }\end{array}$ \\
\hline Haloprogin & $\begin{array}{l}\text { C.a.(山口・岩田, } \\
\text { 1979) }\end{array}$ & & & & 細胞壁多糖合成阻害? \\
\hline Aculeacin A & $\begin{array}{l}\text { C.a.(山口ら, } \\
\text { 1981) }\end{array}$ & $\begin{array}{l}\text { C.a.,S.c.(山口ら, } \\
\text { 1981) }\end{array}$ & & $\begin{array}{l}\text { C.a. (大隅ら, } \\
\text { 1981, 1982; ; 長野 } \\
\text { ら, 1983) }\end{array}$ & 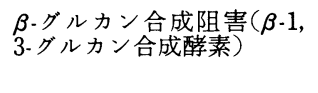 \\
\hline Copiamycin & $\begin{array}{l}\text { C.a. (黒田·石突, } \\
1979 \text { : 新井 } 5, \\
1982 \text { 宇野 } 5, \\
1983 \text {; 新井・宇野, } \\
1985 \text { ) }\end{array}$ & & & & 細胞膜障害? \\
\hline Methiodine & & & & $\begin{array}{l}\text { C. } a \text {. } \text { (大隅ら, } \\
1985)\end{array}$ & 多元的作用機作? \\
\hline
\end{tabular}

a) 実験に使用した菌名の略号

C.a., Candida albicans ; B.d., Blastomyces dermatitidis ; S.c., Saccharomyces cerevisiae ; T.m., Trichophyton mentagrophytes; S.s., Sporothrix schenckii. 
の研究促進が望まれる.最近の研究は次の通りである. （i） M. canis の流動パラフィン重層法（金子・高橋, 1978)，（ii）皮膚糸状菌の継代培養法(金原ら，1980), （iii）皮膚系状菌の蒸溜水保存法(高田ら，1982),（iv） S. schenckii の凍結保存法 (松尾ら, 1979).

\section{抗真菌剤の基礎的研究}

近年, イミダゾール系化合物を中心に新しい抗真菌 剂の開発研究が盛んに行われるようになり，1976 年 clotrimazole が登場して以来, 現在までわが国で上市 された抗真菌剤の数は 14 にものぼっている(表 2 ). これらの薬剤は無論のこと, 既存の抗真菌剂および開 発研究の途上にある抗真菌性物質を含めて, 抗菌活性, 作用機作などに関する基礎的研究が多くの研究グルー プによってなされている。

In vitro 抗菌活性は, 最も基本的な生物学的性状と してすべての薬剤について調べられている。ことに楠 博士 (日医大) らは, 多数の外用抗真菌剂に対する皮 䖉糸状菌臨床分離株の感受性の詳細な比較検討を行っ た（表 2 ）。抗真菌剤以外にも, pepstatin その他の protease inhibitorについてヶラチン培地における抗 皮膚系状菌活性が検討されている(坪井ら，1983）。抗 菌活性 (薬剂感受性) 試験法に関しても幾つかの研究 があり, 皮膚系状菌の切断菌系を接種菌として使用で 导液体三之口培盖法（楠・原田，1981；楠，1982） や平板希棌法または液体希釈法の標準化（品質管理を 含む)（新井ら，1985；阿部ら，1985）などが検討され ている.

体液内薬剤濃度の生物学的検定法として, 寒天抬散 法による測定が flucytosine（岩田ら，1976）および miconazole（岩田ら，1976）についてなされている.

In vitro 抗菌試験にくらべて, in vivo 試験は少数の 薬剂についてのみ行われている(表 2 ). 使用される感 染モデルも限られており，外用剤の場合にはモルモッ トに怙ける T. mentagrophytes 局所感染, また系統的 薬剤にはマウスに打けるC. albicans 静脈内感染が実 験系となっている。モルモットでの実験的白癄は外用 抗真菌剤の薬効評価に繁用される重要なモデルであ り, その評価基準としての局所症状（高橋, 1982）お よび皮膚病巣組織内のキチン含量（内田ら，1984）の 有用性が検証されている。

抗真菌剤の基礎的研究の中心的課題は, 作用機作の 究明にあると考えられる. 表 3 に示されるように，多
数の薬剤について抗菌作用を説明する一次作用点の検 討が行われてきた。方法論としては生理・生化学的ア プローチと超微形態学的アプローチとがある. 前者と しては, (i ) 感受性菌の発育細胞における種々の機能 や代謝活性, (ii) 感受性菌の細胞または動物細胞から 調整した酵素系, または(iii) リン脂質リポソームなど の人工膜モデル系（細胞膜障害作用が想定される薬剂 の場合に限る)に対する薬剤の効果が検討されている. 細胞レベルでの研究に際して問題となるのは, 糸状菌 が実験系として不適当なことであり，したがって酵母 を阻止しない薬剂についてはきわめて実験が困難とな る.この問題は, S. schenckii の酵母形細胞を用いるこ とによってある程度克服されることが分かった（平 谷・山口，1984）。亦た抗菌作用に一次的にかかわる作 用メカニズムを特定するには薬剤耐性または高度感受 性変異株が有用であるところから，C. albicans の呼吸 欠損変異株 (山口・岩田, 1979), イミダゾール剂耐性 変異株(平谷ら，1985), イミダゾール剂高度感受性変 異株（三上ら，1983，1984）が使用され，成果をあげ ている.

一方, 作用機作に対する超徽形態学的アプローチ は, とくに細胞壁合成阻害作用または細胞膜障害作用 をもつ薬剂について有用性が高いはずである。実際 に, 酵母細胞壁 $\beta$-グルカン合成を特異的に阻害する aculeacin A ならびに細胞膜のエルゴステロールおよ びリン脂質とそれぞれ特異的相互作用を営む amphotericin B, イミダゾール剂について種々の電子顕 微鏡学手法により注目すべき研究がなされている（表 3 ).

\section{おわりに}

過去 10 年の間にわが国の医真菌学基礎領域におけ る研究は, その前の 10 年間とは比較にならないほど急 速に進展した。しかし, 真菌症における宿主一寄生体 関係をはじめとする医真菌学の基本的命題に関して は, 従来の方法論は最早限界に達しており, 真の解明 にいたる道程はな打遙かに遠いという感があるのは否 めない事実である、今後新たな飛躍を成しとげるため には, 遺伝学, 遺伝学工学, 分子生物学たどの先端的 な方法論を導入することが不可欠であろう。 また，そ らすることによって, 医真菌学がより近代的で魅力的 な科学となり, 若いすぐれた研究者を多数この分野に 招き入れることも可能となるに違いない. 


\section{Major Topics of Basic Researches}

\section{Hideyo Yamaguchi}

Research Center for Medical Mycology, Teikyo University, 359 Otsuka, Hachioji, Tokyo 192-03, Japan

In order to get insight into the present status and futural trend of basic researches in the field of medical myocology in Japan, almost all the papers dealing with the basic problems and subjects in this discipline which had been presented in the Annual Congress of the Japanese Society for Medical Mycology in the past ten years were collected, categorized and reviewed.

The major categories of reviewed papers refering to medically important fungi and/or mycotic diseases are as follows: (i) life cycle, taxonomy and nomenclature; (ii) asexual reproduction, especially formation of asexual spores; (iii) ultrastructure and cytology; (iv) sexual reproduction and genetics; (v) dimorphism; (vi) physiology and biochemistry; (vii) evaluation of pathogenicity or virulence; (viii) fungal toxins or toxic metabolites assumably associated with pathogenicity; (ix) host-parasite relationship; (x) experimental fungal infections and animal models for mycoses; (xi) biological response modifiers of fungal or bacterial origin (xii) biological and chemical characterization of fungal antigenic components; (xiii) isolation and characterization of fungi from clinical materials; (xiv) techniques for conservation of fungal strains; and (xv) basic problems of antifungal agents and chemotherapy. 